\title{
Action oriented futures studies in Hungary
}

\author{
Erzsébet Nováky * \\ Futures Studies Department, Corvinus University of Budapest, Fövám tér 8. 1093, 1828 Bp 5, \\ P.O. Box: 489, Budapest, Hungary
}

\begin{abstract}
The significant social changes and unstable social-economic processes we are undergoing require more participation and more future oriented grassroots activity both in designing the possible future alternatives and in the actions for the realization of them. Action oriented futures studies and participatory futures studies are in close connection, because orientation towards actions and participation of non-professionals can be strengthened by their mutual interdependence in futures work. This study gives-as examplessummaries of four Hungarian case studies using participatory futures methods: one case from the field of vocational training, two cases concerning regional development, and one about national social-economic development. Our experience shows that such selected groups have evaluated the present issues in their environments as well as the closer and broader regional issues in authentic ways. The future alternatives that were outlined regarding the future of vocational training, acceptable future alternatives of domestic social-economic development, and future living conditions of a smaller settlement and in a larger town, reflected obligation, responsibility and personal interest. That non-professionals lack sufficient future orientation, and do not see possibilities to take serious actions for the future is a read problem. Fortunately, it seems that the future and action oriented attitude of the individuals might be further developed by the use of partnership education.

(C) 2005 Published by Elsevier Ltd.
\end{abstract}

\section{Futures thinking now}

Today futures studies needs to view a multitude of perspectives. This is revealed by accelerating social changes, deeper and involved larger and larger scopes, by the strengthening of the relations and the interdependencies [11], by the increase of complexity [12], and by the social-economic, political and ecological instability, and by the democratization of societies (predominantly in the ex-socialist countries). In order to renew our futures thinking the future is placed into the complex system of time and space [6] and we have managed to establish a new, more proximate relation with the future, than before [26,3]. Less and less we tend to understand

\footnotetext{
* Corresponding author. Tel.: +361482 5325; fax: +3614825378.

E-mail address: erzsebet.novaky@uni-corvinus.hu.
} 
the future merely as the mechanic consequence of the past and the present. Our values are changing $[1,13,14]$, and new future-shaping powers (civic sphere, societal movements) appear to be gaining power on social level.

It has become obvious, that radically new futures, different from the previous ones, need to be realized, because the ones we are heading into through older logic is leading to catastrophe. We search for futures that are attractive or at least acceptable for humankind (i.e. sustainable futures) . We have learnt that different groups in society are asking for and are also receiving a more expressive role in this process. Therefore the participation of grassroots (participatory character) and the significance of their actions for the future (action orientation) are increasing.

The wide-ranging inspiration of grassroots activity is especially important when social changes are significant, when social-economic processes are unstable. The surmises of the population and their expectations towards the future have reached out to the focus of futures work, because currently we are in an unstable period. It is true especially for the ex-socialist countries, which are on their difficult way of transition; their inhabitants are learning the rules of democracy. Situations forecasting radical changes can be observed in all parts of the world (for example in the relation of nation states and globalization, or in coherence with the development of information technology). More and more people realize that they must take part in the shaping of their society's future. Many people demand participation (for example in the form of movements), and increasingly more people devote time and energy for this purpose.

It means futurists can rely and do rely on the ideas, creative thoughts and suggestions of the grassroots more frequently. It is rational to assume, that less and less stable periods are to be expected in the future, because changes have always been even more profound and in-depth during the history. Expectedly the rhythm of changes is going to speed up in the future, that is why participatory futures studies that provokes actions, will gain significance.

Summing up, significant and accelerating social changes and unstable social-economic processes will require more participation of more and more future oriented grassroots both in designing the possible future alternatives and in the actions for realization of them. To assist these is more and more an important tasks of futurists.

\section{Action oriented futures studies and participatory futures studies}

\subsection{Action oriented futures studies}

Action oriented futures studies provokes taking actions [21] and motivates constructive activities that also highlight our creative powers. It does not disclose the possibility of repetitive futures that continue unchanged patterns, but also fights for the realization of futures that are different from the present. Action oriented futures studies understands the present basically in its changing character.

The realization of the importance of being action oriented is not brand new in futures studies. From the beginning of futures studies all scholarly, expert futures research is intended to encourage/enable people to take some kind of action on the basis of research. 'Anticipatory Democracy' activities inspired by Alvin Toffler were well underway in the US and elsewhere. Robert Jungk, Bart van Steenbergen and others were doing similar work in Europe from the late 1960s onward (see e.g. [2]).

The reports of the Club of Rome (see the first one [15]) were also action oriented. They recognized that more or less unchanged continuation of trends might end up in catastrophe, and that we need to have a new way of thinking and take actions in order to avoid this. They believed 
that in order to make change it was necessary for the world's economic, political and academic decision-makers to act in order to avoid 'the chasm ahead' as Aurelio Peccei called it. The suggested action was a therapy to prevent, to avoid the evolvement toward a wrong direction, the negative scenario.

The action oriented futures studies of today not only emphasizes the indispensability of the actions for avoiding crisis situations, but also drives attention toward the fact that if we have positive, ready-to-implementation future alternatives, it is feasible to have increasingly more people to support and implement them. From a popular perspective what is required is even more foresight than just a call for avoiding crises. In crisis situations, even the most committed enemies are willing to forgive offences put their wounds into the background and try to cooperate in order to beat off danger. It is more difficult to convince people to do something for the realization of a good or at least an acceptable future when the danger is not explicit or close. It is comfortable to consider it as natural that good events happen by themselves. People, regardless of their age, sex or qualification, tend to miss opportunities for acting when it is relatively easy to turn the 'wheel of the future' in the right direction.

Fortunately, man belongs to those living creatures that act not only in those cases when a certain need motivates them. People, for example, do not exclusively search for nutrition when hungry, but accumulates it for a rainy day as well. We do not only make shelter that protects us from cold weather when it is cold outside, but also with the foresight to build shelter for the summer. Wise people search for rational opportunities to act. There are many people who take actions, because they have positive thoughts and plans, and they would like to realize them in the most possible rational order and speed.

Research on future orientation and the results of the domestic empirical surveys have led to the revelation of action oriented futures studies. "Future orientation is the characteristics and the capacity, unique to human beings, which enable thinking to be regulated by the past and present, but also to reflect continuously assumptions and expectations regarding the future. The human being is informed not only in space, in the present and immediate future, like many other living creatures, but is also constantly aware to a certain extent of what can be expected beyond his or her immediate environment and over a longer time-horizon." [16]

In our point of view future orientation can be characterized by four components: (1) interest in the future, (2) thinking about the future, (3) activities performed in the interest of the future, (4) expectations for the future. We consider that the most important from the four components is the 'activities performed in the interest of the future', because this catalyzes the passive future relation that manifests in the three-sided unity of 'interest, thinking and expectations'. It means activities have a definite role in shaping the future, while providing an important role to our future shaping power. People who are future oriented in an active way possess an action oriented attitude. In these cases the four components of future orientation are in harmony, that means interest, thinking, and expectations reveal actions.

Increasingly, more futurists emphasize nowadays the importance of taking actions, especially those that practice the critical and the participatory approaches [25], [22]. "You can change the world", as Ervin László in the new report of the Club of Budapest claims [10]. "Humankind can change the world for the better", claims István Kappéter - the title of his book [9]. "In case change is preferred in the expectations (in the aspirations and in the values), this attitude towards the future creates a renewal force"-as I stated in one of our books [18]. The starting point already understood by many people is: for the sake of survival humankind must renew himself: mentally and morally as well as on the level of actions. We need a new kind of thinking and acting. László calls for consciousness and responsibility on behalf of people, Kappéter considers 
small team-work based on conscious and unconscious elements a solution. In my opinion the most important is to realize which tendencies can be changed and cannot be changed among the existing ones. Possible and necessary changes must be accomplished by the society-by creating a future shaping power, of which futurists can help facilitate.

Action orientation in futures studies can serve as a guideline for selecting those among the many possible future alternatives that are acceptable for the world, for certain societies, for groups and individuals in society, and can help point out those actions that can be and should be taken for the sake of the realization of acceptable and sane futures. In this case the emphasis is on the common realization of the jointly found positive futures.

This way action oriented futures studies assumes a novelty-focused approach and a behavior that is oriented to actions. This attitude can be found among the representatives of the sciences as well as non-professionals. Broader stakeholders should participate in shaping the future with sensitivity to the consequences of the actions that are based on such futures thinking, toward coordinated action for the sake of the future.

Action oriented futures studies and participatory futures studies are strongly connected to each other [24]. This opens up the opportunity for futurists, instead of outlining futures alternatives alone (or together with the experts of other sciences), to co-operate with nonprofessionals and act together for their common futures. This interaction provides the possibility for the grassroots to not finish their participation by designing the alternatives but to also take part in acting for the future. Parallel with many others, I also reason that the participation in outlining the alternatives might lead to activity, namely actions taken towards acceptable future alternatives. I also accept that joint and coordinated actions might be more efficient than ones taken separately.

\subsection{Participatory futures studies}

Participatory futures studies - similar to the action oriented futures studies- has roots from the 1960s and 1970s, e.g. [7,8].

Participatory futures studies expresses that all those concerned take part in the process of working out the possible alternatives of the future, whose future is being addressed, and who will take part in realizing it [23]. Futurists formulate future alternatives-that means futures that significantly differ from each other in quality-not exclusively by the involvement of professionals, but also in cooperation with lay non-professionals.

Participatory futures studies helps futurists to:

investigate subjects that a wider population shows interest in and that effects them, widen the range of future alternatives based on the ideas of the grassroots, manage shaping future alternatives in a way that gets closer to the expectations of those for whom they are proposing to shape the future,

reach such a societal consensus, based on a jointly accepted future that can be realized in a harmonic way,

assure the activity of the grassroots to realize the alternatives they desire.

The grassroots may have such a profound future shaping power, that it should be investigated to gain essential information about how the grassroots reacts to instability, how much it can and wishes to influence its own future and also the future of its surroundings, to what extent it is able to work through future alternatives, how willing and able it is to take part in the planning of the 
future, including devoting time and energy for this purpose. We can collect information about the ideas of the grassroots by learning how the grassroots constructs and explains reality, and what expectations are held towards their future. We consider it just as important how nonprofessionals evaluate the present because this evaluation might significantly influence the range and intensity of expectations. For those who accept the present, predominantly those future alternatives can be introduced and then realized that are being created as strict continuation of the present. On the other hand those who do not accept the present might co-operate in the articulation and creation of new type of future alternatives.

When practicing participatory futures studies, what is important is not only the aim to collect opinions formally, but to find creative ideas that might reflect new futures images and explain the factors of development in a new way. It is important that grassroots groups are able and willing to look at the present as critically as possible and see the opportunities provided by the future with as much creativity and as forward-looking as possible. I would like to emphasize the importance of the co-operation of the individual: futurists must be curious and open to the opinion of each participant.

Participatory futures studies cannot just have futurists with academic backgrounds, or the theoretical-methodological knowledge they possess. It is important that professional futurists are not averse from involving lay-persons into the foresight process.

Futurists have defined tasks in each phase of participatory futures studies:

in the preparatory phase the designation of those topics, in that they count on the sincere and creative opinions of non-professionals, lay-people and groups,

in the implementation phase when individual and group opinions are being collected the methodological knowledge of the futurist is indispensable,

in the communication phase the futurist—using his/her synthesizing ability and knowledgeprovides the framework for summarizing the opinion of the grassroots.

The futurist should make sure that participants are selected in a representative way. S/he must think over whom, which organizations, which representatives of the civic sphere and the representatives of which movements should be requested to take part. S/he is responsible for insuring that the topics are introduced on an appropriate level, so that grassroots participants are able to understand them. The futurist needs to use the tools of modern communication so that the voice of those who are physically far away can also be heard, and insure the possibility and conditions for continual feedback must are created. Moreover it is also the task of the futurist to motivate people to take part and help them to express their creative thoughts and ideas. It is important that participants should feel that it is worth devoting their time to addressing issues regarding the difficulties and problems of the community in a future oriented way.

A main characteristic of participatory futures studies is that the participants' judgments, surmises and expectations regarding the future are not neglected, but rather incorporated in the forecasts, strategies and plans that are being worked out on the community level.

\section{Case studies using participatory futures methods in Hungary}

The methods of participatory futures studies have been successfully implemented in three fields in Hungary. First, starting from 1995 to 1996, in the field of education and vocational training, later, in the field of regional development these methods suited the process of 
grounding the regional development project of a small region and a city, and the process of outlining the long-range future alternatives of the national social-economic development.

Our hypotheses was that the grassroots could form valuable and grounded opinions about the present situation, outline visions, hopes and fears about the future, and express a drive for change in these fields. In all these areas, they help shape their long-range future through their activity.

Education is our (students, parents, educators and employees) common business. Without an understanding of the opinions, value judgments and future expectations of non-professionals, futurists and education-planning experts are not be able to work through practical future alternatives and strategies. When the image of a smaller or bigger region, a town, or even a country is to be forecasted, and the possibilities of development are being defined, it is indispensable to articulate and develop the future of the region both short and long term through the involvement of its inhabitants. Citizens have more or less concrete ideas and almost exclusively they possess practical experience with their environment, what is judged or defined as a Good, what developments exist, what is morally/ethically acceptable, and what they would like to change and improve. An expert coming from outside, even though s/he may be an acknowledged expert, cannot know this without an in depth communication process, with inhabitants. The participating citizens help to explore external and internal factors and the mechanism that influence the future of the region; furthermore, they can articulate their ideas and wishes regarding the life and life circumstances of their settlement, their family and themselves in the future.

\subsection{Future alternatives of vocational training in Hungary}

Alternatives and variants of the future of vocational training in Hungary have been worked out by the use of the action oriented futures studies and participatory futures methods [5]. The functional actors of the vocational training system were asked: how they think about the present and the future of vocational training. As experts, teachers working in vocational schools were requested to take part, who expressed their opinions in a two-round experts survey (using the Delphi method), likewise employees articulated their thoughts regarding what kind of expectations they have towards vocational training in a one-round survey. In terms of grassroots participation, primary school and high school students, as well as parents were asked: how satisfied they were with the vocational training, what kind of plans they had for improving their education and their children's education. The $57 \%$ return rate of the questionnaires among the children showed a response to the request that provided creative answers.

The different professional and non-professional opinions that were sent in based on a representative sample were processed separately, and an emphasis was put on the kinds of different opinions explored among the participants. From these, future alternatives reflecting the opinions of their 'own group' were formulated for each group. This was followed by a search for logical equivalence, similarity and differences within the future alternatives. The future statements representing logical equivalences and similarities were connected based on the areas that are important for the future of vocational training (education system, its operation, the content of the training, its labor market competencies, etc). Based on these, complex alternatives and variants were articulated regarding the development of the vocational training in Hungary. For the grassroots participants in the educational system, two alternatives were articulated: in one education is a leading force; in the other it has a following character. 


\subsection{Futures studies foundation of regional development plans}

Using the Delphi method we surfaced opinions among a small regional population for the sake of the implementation of the regional development plan for that region-a settlement called Tuzsér and Small Region called Felső-Szabolcs [17]—and a town called Kiskunfélegyháza [20]. In both surveys the participants were local inhabitants who felt responsibility for the future of their dwelling environment. The percentage of questionnaires' return was $30 \%$ in the small region while it reached $75 \%$ in the town. This latter high rate was reached due to long discussions with the participants, and not through external rewards.

In the case of the forecast for this small region, participants were asked to fill out three consecutive questionnaires. The respondents regarded only few events as probable in the shortterm and there were no economic events among them. A great amount of economic, social, technical and ecological events were forecasted for the next 25 years. Based on the responses coming from the grassroots three alternatives-for economic development, for social development and for social-economic development-were explored. In none of these alternatives, did we experience enthusiasm or a will for cooperation from the side of nonprofessionals.

In the case of the town's forecast we incorporated a phase for analyzing and evaluating the present in the public Delphi. In this phase, the grassroots evaluated those economic processes at a global, European and national level that have an effect on the development of the town. The local government and the civil sphere were also judged. When outlining the alternatives for the town development, we confronted the subjective personal expectations and judgments of local living conditions. The titles of collective, subjective future alternatives - the alternative of a successful future, the alternative of low self-respect, the alternative of hope and the alternative of unsuccessful future-reflect realistically the different level of commitment of inhabitants towards the outlined future alternatives.

In both surveys it is proved, that the remarks, suggestions and future expectations of the grassroots enriched the development plans of the regions significantly. They were especially interested in and anxious for the future of the natural environment and on these areas they gave suggestions that contained novel ideas which deserved to be seriously considered for implementation. Unfortunately, majority of the surveyed inhabitants thought that they themselves could do little for the future of their region, but they found their municipalities competent in helping these regions to flourish in the future.

Through the use of the public Delphi method and the involvement of wider circles in the research process within the small region and town, we helped to foster a spirit in which dealing with their future became-in the noblest sense-a public issue. In these cases the development plan of the small region and of the town was built not on the stereotyped conceptions of some clerks or planners, but on the authentic documents expressing the multitude opinions of the population.

\subsection{Acceptable future alternatives of social-economic development in Hungary}

Acceptable future alternatives of the social-economic development in Hungary has also been created using action oriented futures studies and participatory futures methods [19].

The essence of our approach is that we consciously linked objective possibilities with subjective aspirations, searching for acceptable and unacceptable versions of the future, by exploring the relations between possible future trends deducible from economic and political 
development, and the anticipations and expectations of individuals and social institutions. The approach in its elaboration combined using a top down approach to establish processes for the development of policy and economy, and a bottom up approach to establish the attitude of individuals and social institutions regarding the future. In this framework we juxtaposed the possibilities offered by economic and political conditions, and the anticipations and expectations of the grassroots.

We did not seek the optimal or the desirable future alternative (as the only future image) but explored future alternatives and future images that are not only possible but had already passed the social (public and institutional) test. The criterion of acceptability for all versions of the future is that they ensure latitude for society and its members, and allow the charting of different life and career paths for individuals and progress along those. Searching for latitude in this way also shows that the future must be shaped in unison with the members of Hungarian society and its institutions.

The following methodological steps have helped us search for complex social-economic future alternatives and the future versions leading to them:

We looked for alternatives that belong together, reinforce or weaken each other, i.e. possible futures, by linking the potential alternatives in the development of the world economy and the Hungarian economy with future political scenarios.

We studied the kind of support possible futures would have in Hungarian society. We based our research on the characteristics of the types of expectations in Hungary concerning the country's EU accession, the renewing social and individual values (of goals and means), and the individual aspirations deducible from surveys of future orientation; these provided the future versions, including what is acceptable or not.

We created complex social-economic future alternatives with a view to the dichotomy of possible futures (stable and unstable futures) and the expectations and the attitudes (that want the change and that reject it) towards the future.

Exploring eight future versions and four future alternatives-the alternative of 'plenty of time', the alternative reflecting 'the thinking of revolutionary youth', the alternative of 'missing the boat', the alternative of 'all-or-nothing' — showed us which sets of economic and political alternatives the Hungarian population would prefer, tolerate or reject. Five of the future versions (and two of the future alternatives) cannot be considered as acceptable, while three can. This variety of future versions indicates that the social and economic future of Hungary is not decided yet, so it is still possible to shape and mould it. Recognising the stable and unstable nature of processes prevents society and individuals from wasting their energy on trying to change phenomena that cannot be influenced, thus diverting time and energy from what can be and should be changed.

Importantly, this research showed that a wider variety of actions for the future (working, studying, family, physical and intellectual recreation) prevailed among graduates holding degrees.

\subsection{Application of future information gained by participatory futures methods}

We have used the results that were gained by the use of participatory futures methods for their direct use in motivating the future-shaping actions of stakeholders, for increasing their consciousness, for harmonizing their actions. We have increased that feeling among them that they are not alone; others suffer from analogous future problems and act similarly. The use of these methods have contributed to involving increasingly more people toward a stronger 
foundation for decision-making, so decision-makers and those who are to accept decisions have been brought closer together. Through this we expect the quality of decision-making will improve, as laymen feel a greater motivation, and decision-makers have a greater awareness about their responsibility when making decisions and implementing tasks. Such results can be used indirectly, for the sake of developing the future of a broader environment, as well; because local ideas and actions do have an impact on the future of the broader environment, on the activity of other groups.

Using participatory futures studies motivated taking actions. When the grassroots take part in common work (with faith and commitment) — together with futurists - they help develop participation in the creation of such future alternatives that are possible and also deserving to be strived after.

When searching for the future of vocational training and acceptable social-economic alternatives, the knowledge provided by professionals and non-professionals could be connected organically in such as way that we did not miss important information from either group. In the case of the small region and town's development projects we were not obliged to intervene as futurists in the future work involving non-professionals in order to get acceptable answers (of course the intervention would have changed their opinions). The grassroots proved itself responsible in implementing change, such that we can affirm that interconnection of the participatory and action oriented approach produced acceptable results for exploring the future-a methodological triumph.

\section{Conclusion}

Our initial hypothesis was verified: the Hungarian experience in the application of participatory futures methods shows that selected groups of the population are able to give an adequately complex, authentic picture about the present of their living environment, of their closer and broader region, and it is also feasible to involve grassroots into the systematic search for future variants. The outlined future possibilities have reflected participant obligations, the feeling of responsibility and personal interest. Laymen are mature enough to articulate their opinions and their future expectations, while futurists, using the tools of academic futures studies, can open the process and incorporate these into helping develop future alternatives.

The application of participatory futures studies has motivated both professionals and nonprofessionals to take actions, so the methods of participatory futures studies have strengthened practicing action oriented futures studies, as well. Thus in retrospect one can see a problem in the lack of future-orientation among non-professionals in Hungary, in the limits to the field of vision in the possibilities for serious actions for the future. They do not believe that futurists and later decision-makers will build truly on their opinions or that their activity will provoke significant changes.

In order to overcome these problems education could have a significant role. From this point of view I consider as significantly important to apply and disseminate partnership education as broadly as possible [4]. That aspect and behavior should be taught and reinforced, stakeholders should not only dream about a better future, but be engaged in doing something for it. They must be able to act for a positive future, as well. Partnership education is especially significant in societies in transformation, because it helps us to review our past, and place possible futures into a new view. A society able to cooperate not only create a philosophical foundation for the future, but-based on a positive attitude-takes action for it. This is the main message of the study. 


\section{Acknowledgements}

Thanks to the Hungarian Scientific Research Fund (OTKA) for the grant given to the research program, entitled Change and Future (project coordinator: Erzsébet Nováky, DSc), to my young colleague, Bernadett Szél and Jose Maria Ramos for their linguistic contribution to this article and to the referee for the valuable remarks.

\section{References}

[1] W. Bell, Towards a futurist code of ethics in: R.A. Slaughter (Ed.), The Knowledge Base of Futures Studies 3 , Directions and Outlooks, DDM Media Group, Futures Study Centre, Melbourne, 1996, pp. 97-111.

[2] C. Bezold (Ed.), Anticipatory Democracy: People in the Politics of Future, Random House, New York, 1978.

[3] Y. Dror, Futures studies for contemplation and action in: R.A Slaughter (Ed.), The Knowledge Base of Futures Studies 3, Directions and Outlooks, DDM Media Group, Futures Study Centre, Melbourne, 1996, pp. 85-95.

[4] R. Eisler, Partnership education for the twenty-first century in: J. Gidley, S. Inayatullah (Eds.), Youth Futures. Comparative Research and Transformative Visions, Praeger, Westport, 2002, pp. 43-51.

[5] É. Hideg, E. Nováky, Szakképzés és jövő [Vocational Training and Future], Aula, Budapest, 1998.

[6] S. Inayatullah, Framing the shapes and times of the future: towards a post-development vision of futures in: R.A. Slaughter (Ed.), The Knowledge Base of Futures Studies 3, Directions and Outlooks, DDM Media Group, Futures Study Centre, Melbourne, 1996, pp. 113-127.

[7] R. Jungk, J. Galtung (Eds.), Mankind 2000, Universitetsforlaget, Oslo and Allen\& Unwin, London, 1969.

[8] R. Jungk, N. Müllert, Future Workshops: How to Create Desirable Futures, Institute for Social Inventions, London, 1987.

[9] I. Kappéter, Az emberiség képes jóra változtatni a világot [Humankind Can Change the World for the Better], Püsk, Budapest, 2003.

[10] E. László, Meg tudod változtatni a világot [The Way to Grow], Magyar Könyvklub, Budapest, 2002.

[11] Q. Linzheng, The interdisciplinary construction of the futures field and a new era of integration in: R.A. Slaughter (Ed.), The Knowledge Base of Futures Studies 3, Directions and Outlooks, DDM Media Group, Futures Study Centre, Melbourne, 1996, pp. 41-47.

[12] M. Mannermaa, Coherence chaos and alternative futures, in: R.A. Slaughter (Ed.), The Knowledge Base of Futures Studies 3, Directions and Outlooks, DDM Media Group, Futures Study Centre, Melbourne, 1996, pp. 49-61.

[13] E.B. Masini, International futures perspectives and cultural concepts of the future in: R.A. Slaughter (Ed.), The Knowledge Base of Futures Studies 1, Foundations, DDM Media Group, Futures Study Centre, Melbourne, 1996, pp. 75-85.

[14] E.B. Masini, Values and actions for the future in: E. Nováky, Sz. Fridrik, B. Szél (Eds.), Action for the Future, Budapest Futures Course 2003, Futures Studies Centre, Budapest University of Economic Sciences and Public Administration, Budapest, 2004, pp. 45-54.

[15] D.H. Meadows, D.L. Meadows, J. Randers, W.W. Behrens III., The Limits to Growth, Universe Books, New York, 1972.

[16] SeeE. Nováky, Eacute;. Hideg, I. Kappéter, Future orientation in Hungarian Society, Futures 26 (7) (1994) 759770.

[17] E. Nováky, Tuzsér település és a Felső-Szabolcsi Kistérség jövője (Future of the settlement Tuzsér and the small region Felsô-Szabolcs), Jövőtanulmányok 18. Department of Futures Studies, Budapest University of Economic Sciences and Public Administration, Budapest, 2000.

[18] SeeE. Nováky(Ed.), Magyarország holnap után (Hungary Beyond Tomorrow), Futures Studies Centre, Budapest University of Economic Sciences and Public Administration, Budapest, 2001, p. 58.

[19] SeeE. Nováky(Ed.), Magyarország holnap után (Hungary Beyond Tomorrow), Futures Studies Centre, Budapest University of Economic Sciences and Public Administration, Budapest, 2001, p. 58.

[20] E. Nováky, Kiskunfélegyháza jövője a participatív jövőkutatás szemléletében (Future of the town Kiskunfélegyháza in the participative futures studies point of view(, Jövôtanulmányok 20. Futures Studies Centre, Budapest University of Economic Sciences and Public Administration, Budapest, 2003.

[21] E. Nováky. Cselekvésorientáltság a jövőkutatásban [Action orientation in futures studies], e-Világ, 3(7) (2004) 2-3 
[22] E. Nováky, Participative futures studies in: E. Nováky, Sz. Fridrik, B. Szél (Eds.), Action for the Future, Budapest Futures Course 2003, Futures Studies Centre, Budapest University of Economic Sciences and Public Administration, Budapest, 2004, pp. 67-80.

[23] SeeE. Nováky, Participative futures studies in: E. Nováky, Sz. Fridrik, B. Szél (Eds.), Action for the Future, Budapest Futures Course 2003, Futures Studies Centre, Budapest University of Economic Sciences and Public Administration, Budapest, 2004, pp. 67-80.

[24] J. Ramos, Action research as foresight methodology, Journal of Futures Studies 7 (1) (2002) 1-24.

[25] J.M. Ramos, From Critique to Cultural Recovery, Critical Futures Studies and Causal Layered Analysis, AFI Monograph Series, Australian Foresight Institute, Swinburne, 2003/2.

[26] R.A. Slaughter, Futures concepts in: R.A. Slaughter (Ed.), The Knowledge Base of Futures Studies 1, Foundations, DDM Media Group, Futures Study Centre, Melbourne, 1996, pp. 87-124. 